Web Jurnal:

http://ejournal.kemenperin.go.id/jli

\title{
Karakterisasi busa kaku (rigid foam) yang dihasilkan dari bubuk gambir (Uncaria gambir Roxb.) dengan bubuk albumin
}

\section{Characterization of rigid foam from gambier (Uncaria gambir Roxb.) with the mixing of albumin powder}

\author{
E Efrina*1, Anwar Kasim², Tuty Anggraini', N Novelina ${ }^{2}$ dan Alfi Asben² \\ 1 Graduate Student of Faculty Agricultural Technology, Andalas University \\ Jl. Dr. M. Hatta No 16 Padang, Indonesia \\ 2 Faculty Agricultural Technology, Andalas University \\ Kampus Limau Manis, Padang, Indonesia \\ * e-mail: efrinaherman@gmail.com
}

\begin{tabular}{l}
\hline INFO ARTIKEL \\
\hline Sejarah artikel: \\
Diterima: \\
12 Juli 2019 \\
Direvisi: \\
5 Desember 2019 \\
Diterbitkan: \\
30 Desember 2019
\end{tabular}

Kata kunci: bubuk gambir; bubuk albumin; busa kaku; sel tertutup

\begin{abstract}
ABSTRAK
Salah satu kandungan yang terdapat pada Gambir adalah tanin, tanin memiliki gugus hidroksil dan dapat membentuk senyawa kompleks yang kuat dengan protein. Sifat fenolik dari tanin dapat digunakan sebagai bahan polimer seperti pada pembuatan busa. Busa dapat digunakan sebagai adsorpsi ion logam dan bahan isolasi. Tujuan penelitian adalah untuk mengetahui interaksi antara perbedaan konsentrasi bubuk gambir dengan dua macam bubuk albumin yang digunakan pada pembuatan busa. Penelitian ini menggunakan Rancangan Acak Lengkap (RAL) Faktorial dengan 2 faktor dan 3 ulangan. Faktor A adalah jumlah penggunaan bubuk gambir pada pembuatan busa yaitu $16 \mathrm{~g}$ (A1), $18 \mathrm{~g}$ (A2), $20 \mathrm{~g}$ (A3), $22 \mathrm{~g}$ (A4), $24 \mathrm{~g}$ (A5) untuk setiap perlakuan. Faktor B adalah cara persiapan (preparasi) bubuk albumin yaitu dengan cara pengeringan lapis tipis (B1) dan dengan cara pengembangan busa (B2). Hasil penelitian menunjukkan nilai terbaik untuk kerapatan busa diperoleh pada perlakuan A4B1 yaitu $0.09 \mathrm{~g} / \mathrm{cm}^{3}$, kekuatan tekan pada perlakuan A4B2 yaitu $4.68 \mathrm{~kg} / \mathrm{cm}^{2}$, derajat pengembangan pada perlakuan A4B1 yaitu $53.61 \%$, derajat keasaman pada perlakuan A4B1 yaitu $\mathrm{pH} 7.04$, porositas pada perlakuan A3B2 yaitu 62.03\% dan untuk pengamatan dengan menggunakan alat SEM, keseluruhan struktur mikroskopik busa yang dihasilkan adalah mulai dari berpori, agak rapat-sampai sangat rapat, memiliki diameter yang kecil-sangat besar sehingga busa dapat dikategorikan sebagai busa dengan sel tertutup atau busa kaku.
\end{abstract}

Keywords:

gambir powder; albumin powder; rigid foam; closed cell

\begin{abstract}
One of the ingredients contained in Gambier is tannins, tannins have a hydroxyl group and can form strong complex compounds with proteins. The phenolic properties of tannins can be used as polymer materials as in foam making. Foam can be used as an adsorption of metal ions and insulating materials. This study aims to determined the interaction between different concentration of gambier powder and two kinds of albumin powder to be used in making of foam. This study used Factorial Completely Randomized Design (CRD) with 2 factors and 3 replications. Factor A was the amount of gambier powder which was used in the manufacture of foam, there were $16 \mathrm{~g}(\mathrm{A1}), 18 \mathrm{~g}(\mathrm{A2}), 20 \mathrm{~g}$ (A3), $22 g$ (A4), $24 g$ (A5) for each of treatment. Factor $B$ was the preparation method of albumin, with pan drying (B1) and by foaming drying (B2). The results showed the best value for bulk density is $A 4 B 1\left(0.09 \mathrm{~g} / \mathrm{cm}^{3}\right)$, compressive strength in treatment $A 4 B 2$ $\left(4.68 \mathrm{~kg} / \mathrm{cm}^{3}\right)$, swelling degree in treatment $A 4 B 1(53,61 \%)$, acidity $(\mathrm{pH})$ in treatment $A 4 B 1$ (7.04), porocity in treatment A3B2 (62.03\%) and for SEM observations the entire microscopic structure of the foam produced is starting from porous, rather dense to very tight, having a small diameter until large, so that foam can be categorized as foam with rigid foam (closed cells).
\end{abstract}




\section{Pendahuluan}

Gambir (Uncaria gambir Roxb) adalah tanaman dengan komponen utamanya berupa katekin dan tanin (Kasim, 2011). Tanin juga dapat digunakan sebagai agen untuk mengikat partikel dan fiber boards (Roffael et al., 2000) serta juga dapat digunakan dalam pembuatan busa sebagai bahan isolator (Tondi and Pizzi, 2009 ; Lagel et al., 2014). Beberapa tahun terakhir, busa berbasis tanin diperoleh dari $95 \%$ substrat alami. Hasil ini berdasarkan pada keramahan terhadap lingkungan karena bersifat alami (Tondi et al., 2010).

Busa secara komersial (busa Polyurethane / PUR) dihasilkan dari polyol yang dibuat secara sintetis dari produk turunan petroleum (Rahmawati et al., 2012) dan pada umumya menggunakan pengembang (blowing agent) seperti hydrochlorofluorocarbon (HCFC), clorofluorocarbon (CFC) dan senyawa organik yang mudah menguap seperti methylene chloride, namun blowing agent tersebut dapat menyebabkan gangguan kesehatan dan kerusakan lingkungan (Toshima, 1994).

Penelitian terbaru yang dilakukan oleh (Lacoste et al., 2015) pada pembuatan busa berbasis tanin dari kayu Quebracho, pohon Pinus (Pinus radiate), pohon Pinus Maritime (Pinus pinaster) dan kulit kayu Cemara (Picea abies) yang dikombinasikan dengan protein dari albumin didasarkan atas sifat dari tanin yang dapat berikatan kuat dengan protein.

Tanin memiliki kemampuan dalam mengikat protein yang mengandung struktur organik (Lacoste et al., 2015), sehingga diperkirakan dapat digunakan sebagai bahan dalam pembuatan busa yang dikombinasikan dengan protein dari albumin telur itik.

Sehubungan dengan hal ini maka dalam pembuatan busa dapat dihasilkan dari bahan alami yang lebih murah dan terjangkau. Salah satu bahan alami yang berpotensi digunakan adalah gambir (bubuk gambir). Gambir yang berasal dari daerah 50 kota memilik kadar tanin $>20 \%$ yaitu 30,31\% (Malrianti et al., 2011).

Tujuan penelitian ini adalah untuk mengetahui interaksi antara perbedaan konsentrasi bubuk gambir dengan dua macam bubuk albumin yang digunakan dalam pembuatan busa. Penggunaan tanin yang berasal dari gambir dalam pembuatan busa dapat menunjang penggunaan gambir dalam bentuk lain serta untuk mengetahui hasil busa dari penggunaan bubuk gambir.

\section{Metode}

Bahan utama dalam pembuatan busa ini adalah gambir yang diperoleh dari Muaro Paiti, 50 KotaSumatera Barat dan albumin telur itik (itik tegal / Anas javanica) sebagai bahan tambahan, sedangkan bahan yang dicampurkan untuk proses pembuatan adalah paraToluena Sulfonic Acid (pTSA) sebagai katalis dan hexamin sebagai pengeras.

Peralatan yang digunakan meliputi magnetic stirrer merk AREC Velp Scientifica-Europe, ultrasonic bath merk Elma S300H, set vakum evaporator merk Buchi R215, Germany, mixer merk Philip, alat uji kuat tekan merk Cesare Galdabini Gallaret-Italia, $\mathrm{pH}$ meter (Delta OHM HD 2105.2, Italy), scanning electron microscope merk Hitachi-S3400 N, Jepang, oven (Philip Harris Ltd), timbangan analitik (Kern ABJ 220-4M, Germany) dan lain-lain.

\subsection{Rancangan penelitian}

Penelitian ini menggunakan Rancangan Acak Lengkap Faktorial (RAL Faktorial) untuk menunjukkan pengaruh perbedaan jumlah penambahan bubuk gambir dan pemakaian dua macam bubuk albumin serta interaksi keterkaitan antara perlakuan faktor A dan faktor B.

Faktor pertama (A) adalah jumlah perbedaan penambahan bubuk gambir yaitu $16 \mathrm{~g}$ (A1), $18 \mathrm{~g}$ (A2), $20 \mathrm{~g}$ (A3), $22 \mathrm{~g}$ (A4), dan $24 \mathrm{~g}$ (A5) sedangkan faktor kedua (B) adalah cara menghasilkan bubuk albumin yaitu dengan cara pan drying (B1) dan dengan cara foaming drying (B2).

Penggunaan RAL faktorial pada penelitian ini yaitu dengan 2 faktor dan 3 ulangan. Jika hasil hitungan statistik (Uji F) menunjukkan berbeda nyata dilanjutkan dengan uji lanjutan DNMRT pada taraf 5\%.

\subsection{Pelaksanaan penelitian}

\subsubsection{Preparasi bubuk gambir sebagai bahan utama busa}

Gambir yang diperoleh dari Muaro Paiti-50 Kota, dihaluskan hingga lolos ayakan 80 mesh, untuk selanjutnya digunakan sebagai bahan utama dalam pembuatan busa.

\subsubsection{Preparasi bubuk albumin dengan metode pengeringan lapis tipis (pan drying) dan metode pengembangan busa (foaming drying)}

a. Bubuk albumin metode pengeringan lapis tipis (pan drying) modifikasi (Romanoff and Romanoff, 1949)

Putih telur dan kuning telur terlebih dahulu dipisahkan, putih telur dimasukkan ke dalam loyang berukuran $25,5 \mathrm{~cm}$ x $25,5 \mathrm{~cm}$ dan masukkan ke dalam oven (suhu $85^{\circ} \mathrm{C}, \pm 26 \mathrm{jam}$ ). setelah itu haluskan hingga lolos saringan 80 mesh.

\section{b. Bubuk albumin metode pengembangan busa (foaming drying) modifikasi (Sirait, 1986)}

Putih telur dan kuning telur terlebih dahulu dipisahkan, putih telur dikocok dengan menggunakan mixer ( \pm 20 menit, $900 \mathrm{rpm}$ ), lalu dimasukkan ke dalam loyang berukuran $25,5 \mathrm{~cm}$ x $25,5 \mathrm{~cm}$ dan keringkan dalam oven (suhu $85^{\circ} \mathrm{C}, \pm 12 \mathrm{jam}$ ). setelah itu haluskan hingga lolos saringan 80 mesh.

\subsubsection{Pembuatan busa kaku (Lacoste et al., 2015)}

Bubuk albumin sebanyak 23 g dicampur dengan air lalu dikocok \pm 10 menit sampai homogen dengan kecepatan pengadukan 1400 rpm. Tambahkan bubuk gambir sesuai perlakuan, hexamine dan pTSA. Aduk sampai diperoleh emulsi yang homogen dan berbentuk busa cair, kemudian dimasukkan ke oven pada suhu $85^{\circ} \mathrm{C}$ selama \pm 2 jam. 


\subsubsection{Pengamatan}

Pengamatan pada penelitian ini meliputi kerapatan busa (Szczurek et al., 2014), kekuatan tekan (Lacoste et al., 2015), derajat pengembangan (Rohaeti and Suyanta, 2011), pH modifikasi (Lacoste et al., 2015), porositas (Lacoste et al., 2015), pengamatan pori busa dengan alat Scanning Electron Microscope (Rohaeti and Suyanta, 2011).

\section{Hasil dan pembahasan 3.1 Kerapatan busa}

Kerapatan yang lebih kecil dapat diperoleh dengan penambahan bubuk albumin yang dipersiapkan dengan metode pan drying dan untuk semua perlakuan memenuhi kriteria busa kaku. Semakin tinggi nilai kerapatan busa maka daya hantar panas (konduktivitas termalnya) juga semakin tinggi (Lacoste et al., 2015). Nilai kerapatan busa dapat dilihat pada Tabel 1.

Tabel 1.

Nilai kerapatan busa kaku $\left(\mathrm{g} / \mathrm{cm}^{3}\right)$

\begin{tabular}{|c|c|c|}
\hline \multirow{2}{*}{$\begin{array}{l}\text { Faktor A } \\
\text { (Penambahan } \\
\text { Bubuk Gambir) }\end{array}$} & \multicolumn{2}{|c|}{ Faktor B (Bubuk Albumin) } \\
\hline & $\begin{array}{l}\text { B1 } \\
\text { (Pan Drying) }\end{array}$ & $\begin{array}{l}\text { B2 } \\
\text { (Foaming Drying) }\end{array}$ \\
\hline A1 (16 g) & $\underset{\mathbf{B}}{0,12 \pm 0,01 \mathbf{a}}$ & $\begin{array}{c}0,13 \pm 0,00 \mathbf{b} \\
\mathbf{A}\end{array}$ \\
\hline A2 (18 g) & $0,14 \pm 0,00 \mathbf{a}$ & $\begin{array}{c}0,16 \pm 0,00 \mathbf{b} \\
\mathbf{D}\end{array}$ \\
\hline A3 $(20 \mathrm{~g})$ & $\begin{array}{c}0,15 \pm 0,01 \mathbf{a} \\
\mathbf{D}\end{array}$ & $\begin{array}{c}0,16 \pm 0,01 \mathbf{b} \\
\mathbf{D}\end{array}$ \\
\hline A4 (22 g) & $\begin{array}{c}0,09 \pm 0,01 \mathbf{a} \\
\mathbf{A}\end{array}$ & $\begin{array}{l}0,14 \pm 0,01 \mathbf{b} \\
\mathbf{B}\end{array}$ \\
\hline A5 (24 g) & $\begin{array}{c}0,14 \pm 0,01 \mathbf{a} \\
\mathbf{C}\end{array}$ & $\begin{array}{l}0,15 \pm 0,01 \mathbf{b} \\
\mathbf{C}\end{array}$ \\
\hline
\end{tabular}

$\mathrm{KK}(\%)=0,44$

Keterangan: angka yang diikuti huruf yang sama tidak berbeda nyata menurut Uji Duncan pada taraf nyata $5 \%$. Huruf kecil dibaca arah horizontal (kolom) huruf besar dibaca arah vertikal (baris)

Pada Tabel 1 dapat dilihat bahwa nilai kerapatan busa terendah didapatkan pada perlakuan penambahan bubuk gambir $22 \mathrm{~g}$ dan bubuk albumin dengan cara pan drying yaitu $0,09 \mathrm{~g} / \mathrm{cm}^{3}$, diikuti oleh perlakuan dengan penambahan bubuk gambir $16 \mathrm{~g}$ dan bubuk albumin dengan cara pan drying yaitu $0,12 \mathrm{~g} / \mathrm{cm}^{3}$, perlakuan dengan penambahan bubuk gambir $16 \mathrm{~g}$ dan bubuk albumin dengan cara foaming drying yaitu $0,13 \mathrm{~g} / \mathrm{cm}^{3}$, sedangkan perlakuan dengan penambahan bubuk gambir $24 \mathrm{~g}$ dan bubuk albumin dengan car pan drying serta penambahan bubuk gambir $22 \mathrm{~g}$ dan bubuk albumin dengan cara foaming drying memiliki nilai kerapatan busa yang sama yaitu $0,14 \mathrm{~g} / \mathrm{cm}^{3}$, perlakuan dengan penambahan bubuk gambir $20 \mathrm{~g}$ dan bubuk albumin dengan car pan drying, perlakuan dengan penambahan bubuk gambir $24 \mathrm{~g}$ dan bubuk albumin dengan cara foaming drying memiliki nilai kerapatan busa yang juga sama yaitu $0,15 \mathrm{~g} / \mathrm{cm}^{3}$. Nilai kerapatan tertinggi diperoleh pada perlakuan penambahan bubuk gambir $18 \mathrm{~g}$ dan $20 \mathrm{~g}$ dan bubuk albumin dengan cara foaming drying yaitu $0,16 \mathrm{~g} / \mathrm{cm}^{3}$ (dengan nilai kerapatan busa yang sama).

Penambahan bubuk gambir dan metode dalam pembuatan bubuk albumin berpengaruh nyata $(\mathrm{P}<0.05)$ terhadap nilai kerapatan kerapatan busa yang dihasilkan serta terjadi interaksi yang berpengaruh nyata $(\mathrm{P}<0.05)$ antara jumlah penambahan bubuk gambir dengan bubuk albumin terhadap nilai kerapatan busa yang dihasilkan.

Busa padat dengan kerapatan yang lebih kecil dapat diperoleh dengan penambahan bubuk albumin yang diperoleh dengan metode pan drying. Busa padat adalah busa yang memiliki kerapatan dengan nilai $<0,3 \mathrm{~g} / \mathrm{cm}^{3}$ (Lacoste et al., 2015). Kerapatan (density) adalah faktor utama dalam menentukan sifat suatu bahan terutama kekuatan mekaniknya (Firdaus, 2014).

\subsection{Kekuatan tekan}

Nilai kuat tekan busa yang dihasilkan semakin meningkat dengan penambahan konsentrasi bubuk gambir. Nilai kekuatan tekan busa dapat dilihat pada Tabel 2.

Tabel 2.

Nilai kekuatan tekan busa kaku $\left(\mathrm{kg} / \mathrm{cm}^{2}\right)$

\begin{tabular}{|c|c|c|}
\hline \multirow{2}{*}{$\begin{array}{l}\text { Faktor A } \\
\text { (Penambahan } \\
\text { Bubuk Gambir) }\end{array}$} & \multicolumn{2}{|c|}{ Faktor B (Bubuk Albumin) } \\
\hline & $\begin{array}{l}\text { B1 } \\
\text { (Pan Drying) }\end{array}$ & $\begin{array}{l}\text { B2 } \\
\text { (Foaming Drying) }\end{array}$ \\
\hline A1 (16 g) & $\begin{array}{c}1,53 \pm 0,37 \mathbf{a} \\
\mathbf{B}\end{array}$ & $\begin{array}{c}2,68 \pm 0,11 \mathbf{b} \\
\mathbf{A}\end{array}$ \\
\hline A2 (18 g) & $\begin{array}{c}3,33 \pm 0,95 \mathbf{a} \\
\mathbf{C}\end{array}$ & $\begin{array}{c}3,72 \pm 0,51 \mathbf{b} \\
\mathbf{C}\end{array}$ \\
\hline A3 (20 g) & $\begin{array}{c}1,34 \pm 0,14 \mathbf{a} \\
\mathbf{A}\end{array}$ & $\begin{array}{c}3,17 \pm 0,28 \mathbf{b} \\
\mathbf{B}\end{array}$ \\
\hline A4 (22 g) & $\begin{array}{c}1,50 \pm 0,11 \mathbf{a} \\
\mathbf{B}\end{array}$ & $\begin{array}{c}4,68 \pm 0,98 \mathbf{b} \\
\mathbf{E}\end{array}$ \\
\hline A5 $(24 \mathrm{~g})$ & $\begin{array}{c}3,27 \pm 0,05 \mathbf{a} \\
\mathbf{C}\end{array}$ & $\begin{array}{c}4,28 \pm 0,05 \mathbf{b} \\
\mathbf{D}\end{array}$ \\
\hline
\end{tabular}

$\mathrm{KK}(\%)=4,14$

Keterangan: angka yang diikuti huruf yang sama tidak berbeda nyata menurut Uji Duncan pada taraf nyata 5\%. Huruf kecil dibaca arah horizontal (kolom) huruf besar dibaca arah vertikal (baris)

Nilai kuat tekan tertinggi didapatkan pada perlakuan penambahan bubuk gambir $24 \mathrm{~g}$ dan bubuk albumin dengan cara foaming drying yaitu $4,28 \mathrm{~kg} / \mathrm{cm}^{2}$ dan terkecil diperoleh pada perlakuan penambahan bubuk gambir $20 \mathrm{~g}$ dan bubuk albumin dengan cara pan drying yaitu $1,34 \mathrm{~kg} / \mathrm{cm}^{2}$

Terjadinya peningkatan nilai kuat tekan dari busa yang dihasilkan seiring bertambahnya jumlah penambahan bubuk gambir, dan terjadi interaksi $(\mathrm{P}<0.05)$ antara penambahan bubuk gambir dan metode pembuatan bubuk albumin terhadap nilai kekuatan tekan busa. Peningkatan penambahan bubuk gambir menunjukkan bahwa tanin yang terdapat pada gambir 
tersebut tinggi sehingga nilai kuat tekan busa yang diperoleh juga tinggi.

Nilai suatu kuat tekan juga berpengaruh dari banyak hal, salah satunya adalah bentuk spesimen yang digunakan atau yang akan diukur. Bentuk kubus dan silinder sangat menentukan kuat tekan suatu bahan. Pengaplikasian busa kaku yang dihasilkan dari penelitian ini adalah salah satunya untuk isolasi bahan bangunan. Pengukuran kuat dengan dengan menggunakan spesimen berbentuk kubus lebih diminati dari pada specimen berbentuk silinder (Haji et al., 2012).

\subsection{Derajat pengembangan}

Derajat pengembangan bertujuan untuk mengetahui kapasitas material dalam menyerap cairan sampai terjadi kesetimbangan. Nilai kekuatan tekan busa dapat dilihat pada Tabel 3.

Tabel 3.

Nilai derajat pengembangan busa kaku (\%)

\begin{tabular}{|c|c|c|}
\hline \multirow{3}{*}{$\begin{array}{l}\text { Faktor A } \\
\text { (Penambahan } \\
\text { Bubuk Gambir) }\end{array}$} & \multicolumn{2}{|c|}{ Faktor B (Bubuk Albumin) } \\
\hline & B1 & B2 \\
\hline & (Pan Drying) & (Foaming Drying) \\
\hline A1 (16 g) & $\begin{array}{c}46,29 \pm 1,39 \text { b } \\
\mathbf{C}\end{array}$ & $\begin{array}{c}16,89 \pm 1,76 \mathbf{a} \\
\mathbf{C}\end{array}$ \\
\hline A2 (18 g) & $\begin{array}{c}34,42 \pm 1,99 \mathbf{b} \\
\mathbf{A}\end{array}$ & $\begin{array}{c}15,41 \pm 2,05 \mathbf{a} \\
\mathbf{B}\end{array}$ \\
\hline A3 $(20 \mathrm{~g})$ & $\begin{array}{c}49,38 \pm 1,98 \mathbf{b} \\
\mathbf{D}\end{array}$ & $\begin{array}{c}10,51 \pm 6,20 \mathbf{a} \\
\mathbf{A}\end{array}$ \\
\hline A4 (22 g) & $\begin{array}{c}53,61 \pm 3,02 \mathbf{b} \\
\mathbf{E}\end{array}$ & $\begin{array}{c}29,00 \pm 2,38 \mathbf{a} \\
\mathbf{D}\end{array}$ \\
\hline A5 $(24 \mathrm{~g})$ & $\begin{array}{c}43,42 \pm 1,71 \text { b } \\
\text { B }\end{array}$ & $\begin{array}{c}15,73 \pm 3,48 \mathbf{a} \\
\mathbf{B}\end{array}$ \\
\hline
\end{tabular}

$\mathrm{KK}(\%)=9,94$

Keterangan: angka yang diikuti huruf yang sama tidak berbeda nyata menurut Uji Duncan pada taraf nyata 5\%. Huruf kecil dibaca arah horizontal (kolom) huruf besar dibaca arah vertikal (baris)

Derajat pengembangan busa dengan nilai yang bervariasi dengan kisaran nilai antara 10-53\%. Derajat pengembangan tertinggi diperoleh pada perlakuan penambahan bubuk gambir $24 \mathrm{~g}$ dan bubuk albumin dengan cara pan drying yaitu 53,61\% dan terendah yaitu perlakuan penambahan bubuk gambir $20 \mathrm{~g}$ dan bubuk albumin dengan cara foaming drying yaitu $10,51 \%$.

Hasil penelitian Link et al., 2011 menyatakan bahwa untuk busa kaku nilai derajat pengembangan busa kaku yaitu berkisar antara 10\%-60\% sedangkan penelitian yang dilakukan oleh (Anova et al., 2018) nilai derajat pengembangan terendah diperoleh yaitu dengan nilai $54,90 \%$. Hal ini menunjukkan jika derajat pengembangan busa kaku pada penelitian ini yang paling baik adalah dengan menggunakan bubuk albumin metode pembuatan pan drying dan perlakuan yang mendekati nilai paling tepat yaitu perlakuan penambahan bubuk gambir $24 \mathrm{~g}$ dan bubuk albumin dengan cara pan drying yaitu 53,61\%. Penambahan konsentrasi bubuk gambir dan albumin berpengaruh nyata dan terjadi interaksi $(\mathrm{P}<0.05)$ terhadap nilai derajat pengembangan.
Hasil penelitian Rohaeti and Suyanta, 2011 menyatakan bahwa dari hasil nilai pengembangan yang diperoleh dapat dilihat terjadi atau tidaknya ikatan silang antara bahan-bahan penyusun dalam sintesis busa. Semakin besar nilai pengembangan maka berarti nilai bernilai positif karena terjadinya ikatan silang dalam strukturnya, air yang digunakan sebagai pelarut dapat menembus jaringan pada busa sedangkan busa dengan nilai rendah menandakan jaringan busa rapat dan molekul air sulit menembus jaringan busa.

\subsection{Derajat keasaman atau nilai pH}

Nilai $\mathrm{pH}$ busa kaku yang dihasilkan dapat dilihat pada Tabel 4. Nilai $\mathrm{pH}$ yang didapatkan berkisar antara 7,04-7,78. Nilai pH terrendah didapatkan pada perlakuan penambahan bubuk gambir $24 \mathrm{~g}$ dan bubuk albumin dengan cara pan drying yaitu 7,04 dan tertinggi pada perlakuan penambahan bubuk gambir $24 \mathrm{~g}$ dan bubuk albumin dengan cara foaming drying yaitu 7,78. Menurut Lacoste et al (2015) bahwa nilai pH busa berbasis tanin dan albumin yaitu 7,1 .

Tabel 4.

Nilai $\mathrm{pH}$ busa kaku

\begin{tabular}{|c|c|c|}
\hline \multirow{2}{*}{$\begin{array}{l}\text { Faktor A } \\
\text { (Penambahan } \\
\text { Bubuk Gambir) }\end{array}$} & \multicolumn{2}{|c|}{ Faktor B (Bubuk Albumin) } \\
\hline & $\begin{array}{l}\text { B1 } \\
\text { (Pan Drying) }\end{array}$ & $\begin{array}{l}\mathrm{B} 2 \\
\text { (Foaming Drying) }\end{array}$ \\
\hline A1 (16 g) & $\begin{array}{c}7,40 \pm 0,00 \mathbf{a} \\
\mathbf{B}\end{array}$ & $\begin{array}{c}7,68 \pm 0,03 \mathbf{b} \\
\mathbf{B}\end{array}$ \\
\hline A2 (18 g) & $\begin{array}{c}7,69 \pm 0,04 \mathbf{a} \\
\mathbf{C}\end{array}$ & $\begin{array}{c}7,60 \pm 0,01 \mathbf{b} \\
\mathbf{B}\end{array}$ \\
\hline A3 (20 g) & $\begin{array}{c}7,17 \pm 0,03 \mathbf{a} \\
\mathbf{A}\end{array}$ & $\begin{array}{c}7,29 \pm 0,03 \mathbf{b} \\
\mathbf{A}\end{array}$ \\
\hline A4 (22 g) & $\begin{array}{c}7,04 \pm 0,02 \mathbf{a} \\
\mathbf{A}\end{array}$ & $\begin{array}{c}7,30 \pm 0,06 \mathbf{b} \\
\mathbf{A}\end{array}$ \\
\hline A5 $(24 \mathrm{~g})$ & $\begin{array}{c}7,34 \pm 0,09 \mathbf{a} \\
\mathbf{B}\end{array}$ & $\begin{array}{c}7,78 \pm 0,01 \mathbf{b} \\
\mathbf{C}\end{array}$ \\
\hline
\end{tabular}

$\mathrm{KK}(\%)=0,31$

$\overline{\text { Keterangan: angka yang diikuti huruf yang sama tidak berbeda }}$ nyata menurut Uji Duncan pada taraf nyata 5\%. Huruf kecil dibaca arah horizontal (kolom) huruf besar dibaca arah vertikal (baris)

Penambahan bubuk gambir dan metode pembuatan bubuk albumin berpengaruh nyata terhadap nilai $\mathrm{pH}$ busa yang dihasilkan dan untuk interaksi antara konsentrasi bubuk gambir dan metode pembuatan bubuk albumin juga berpengaruh nyata $(\mathrm{P}<0.05)$ terhadap nilai $\mathrm{pH}$ busa. Nilai $\mathrm{pH}$ untuk busa yang paling baik atau mendekati standar yaitu busa dengan penambahan bubuk albumin yang diperoleh dengan metode pan drying. Sesuai juga dengan penelitian yang dilakukan oleh Lacoste et al (2015) bahwa pembuatan bubuk albumin dengan metode pan drying akan menghasilkan nilai $\mathrm{pH}$ busa yang tidak terlalu tinggi.

\subsection{Porositas}

Porositas adalah perbandingan antara densiti busa dan densiti bahan-bahan utama penyusun busa (Lacoste 
et al., 2015). Porositas busa merupakan salah satu parameter penting, porositas akan menentukan penampakan ukuran mikroskopik busa yang dihasilkan serta berkaitan erat dengan kerapatan dan kekuatan tekan busa yang dihasilkan. Nilai porositas busa dapat dilihat pada Tabel 5 berikut ini.

Tabel 5.

Nilai porositas busa kaku (\%)

\begin{tabular}{|c|c|c|}
\hline \multirow{2}{*}{$\begin{array}{c}\text { Faktor A } \\
\text { (Penambahan } \\
\text { Bubuk Gambir) }\end{array}$} & \multicolumn{2}{|c|}{ Faktor B (Bubuk Albumin) } \\
\hline & $\mathrm{B} 1$ & B2 \\
\hline A1 $(16 \mathrm{~g})$ & $\begin{array}{c}71,08 \pm 1,97 \mathbf{b} \\
\mathbf{C}\end{array}$ & $\begin{array}{c}69,29 \pm 0,61 \mathbf{a} \\
\text { D }\end{array}$ \\
\hline A2 (18 g) & $\begin{array}{c}65,71 \pm 0,35 \mathbf{b} \\
\mathbf{B}\end{array}$ & $\begin{array}{c}62,31 \pm 0,70 \mathbf{a} \\
\mathbf{A}\end{array}$ \\
\hline A3 (20 g) & $\begin{array}{c}64,87 \pm 2,81 \mathbf{b} \\
\mathbf{A}\end{array}$ & $\begin{array}{c}62,03 \pm 1,68 \mathbf{a} \\
\mathbf{A}\end{array}$ \\
\hline A4 (22 g) & $\begin{array}{c}79,66 \pm 3,44 \mathbf{b} \\
\text { D }\end{array}$ & $\begin{array}{c}65,60 \pm 2,01 \mathbf{a} \\
\mathbf{C}\end{array}$ \\
\hline A5 (24 g) & $\begin{array}{c}65,03 \pm 2,42 \mathbf{b} \\
\mathbf{B}\end{array}$ & $\begin{array}{c}64,53 \pm 2,59 \mathbf{a} \\
\mathbf{B}\end{array}$ \\
\hline
\end{tabular}

$\mathrm{KK}(\%)=4,69$

$\overline{\text { Keterangan: angka yang diikuti huruf yang sama tidak berbeda }}$ nyata menurut Uji Duncan pada taraf nyata 5\%. Huruf kecil dibaca arah horizontal (kolom) huruf besar dibaca arah vertikal (baris)

Nilai porositas busa berbasis tanin dan albumin yang tertinggi didapatkan pada ke dua faktor yaitu pada perlakuan penambahan bubuk gambir $24 \mathrm{~g}$ dan bubuk albumin dengan cara pan drying yaitu $79,66 \%$ dan perlakuan penambahan bubuk gambir $16 \mathrm{~g}$ dan bubuk albumin dengan cara foaming drying yaitu 69,29\% sedangkan nilai porositas terendah diperoleh pada perlakuan penambahan bubuk gambir $20 \mathrm{~g}$ dan bubuk albumin dengan cara pan drying yaitu $64,87 \%$ dan perlakuan penambahan bubuk gambir $20 \mathrm{~g}$ dan bubuk albumin dengan cara foaming drying yaitu $62,03 \%$. Dilihat dari penelitian yang telah dilakukan oleh (Lacoste et al., 2015) kategori busa yang termasuk sebagai busa kaku adalah dengan nilai porositas maksimal $68 \%$, sehingga bisa dikatakan untuk perlakuan penambahan bubuk gambir $18 \mathrm{~g}, 20 \mathrm{~g}$ dan $24 \mathrm{~g}$ dengan bubuk albumin cara pan drying serta perlakuan penambahan bubuk gambir $18 \mathrm{~g}, 20 \mathrm{~g}, 22 \mathrm{~g}$ dan $24 \mathrm{~g}$ dengan bubuk albumin cara foaming drying sebagai busa dengan sel tertutup (busa kaku).

Konsentrasi penambahan bubuk gambir dan metode pembuatan bubuk albumin pada perlakuan pada penambahan bubuk gambir $24 \mathrm{~g}$ dan bubuk albumin dengan cara pan dryin, penambahan bubuk gambir $16 \mathrm{~g}$ dan 22 g dengan bubuk albumin cara foaming drying tidak memberikan pengaruh yang nyata pada nilai porositas yang dihasilkan. Namun secara garis besar konsentrasi penambahan bubuk gambir dan bubuk albumin berpengaruh nyata $(\mathrm{P}<0.05)$ terhadap nilai porositas yang dihasilkan dan interaksi antara penambahan bubuk gambir dan metode pembuatan bubuk albumin juga berpengaruh nyata $(\mathrm{P}<0.05)$ terhadap nilai porositas busa kaku yang dihasilkan.
Perubahan jumlah pemakaian bubuk gambir akan mengubah hasil nilai porositas dan ukuran sel yang dihasilkan, selain dari pemakaian konsentrasi bubuk gambir, kecepatan pengadukan, waktu pengadukan, penambahan surfaktan dan lama pemasakan juga akan mempengaruhi hasil dari porositas (Szczurek et al., 2014). Nilai porositas yang tinggi akan menyebabkan kekuatan tekan busa juga rendah hal ini juga disebabkan oleh terjadinya penguapan air pada busa.

\subsection{Pengamatan mikroskopik busa dengan metode SEM (Scanning Electron Microscop)}

Scanning Electron Microscopy (SEM) merupakan sejenis mikroskop yang menggunakan elektron sebagai pengganti cahaya untuk melihat benda dengan resolusi tinggi. SEM bermanfaat untuk mengetahui mikrostruktur (termasuk porositas dan bentuk retakan) benda padat. Berkas sinar elektron dihasilkan dari filamen yang dipanaskan, disebut electron gun (Gunawan and Azhari, 2010). Hasil pengamatan yang telah dilakukan terhadap bentuk dan struktur pori dilakukan dengan menggunakan alat foto SEM merk Hitachi S-3400 N dengan perbesaran 150 x dapat dilihat pada Gambar 1-10.

Perbedaan konsentrasi penambahan bubuk gambir dan bubuk albumin dalam proses pembuatan busa akan menghasilkan busa yang berbeda baik untuk nilai kerapatan, porositas dan penampakan mikroskopik maupun ukuran sel (Szczurek et al., 2014). Porositas berkaitan erat dengan penampakan mikroskopik atau struktur busa, semakin kecil nilai porositas busa maka struktur pori yang dihasilkan juga akan semakin rapat. Nilai porositas yang tinggi akan menghasilkan struktur pori busa yang besar dan jumlah pori yang banyak.

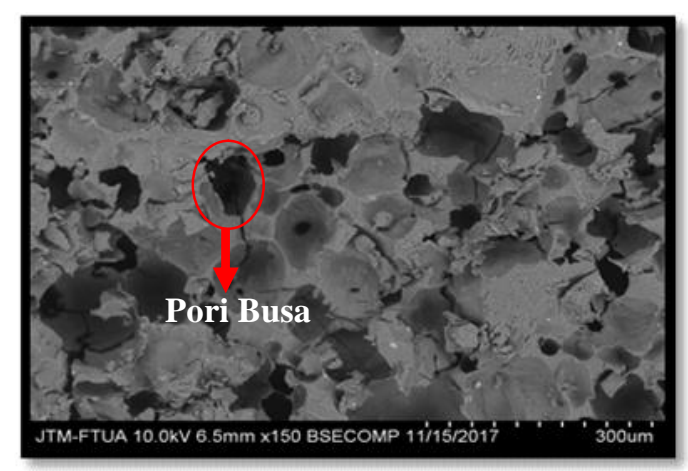

Gambar 1. Penambahan bubuk gambir $16 \mathrm{~g}$ : bubuk albumin metode pan drying (A1B1)

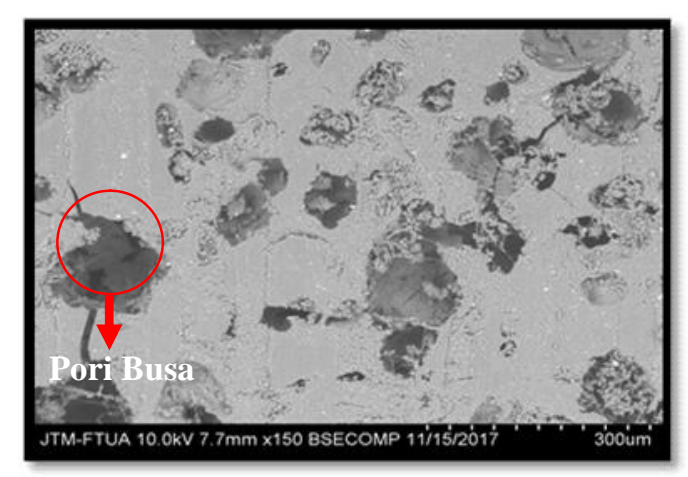

Gambar 2. Penambahan bubuk gambir $16 \mathrm{~g}$ : bubuk albumin metode foaming drying (A1B2) 


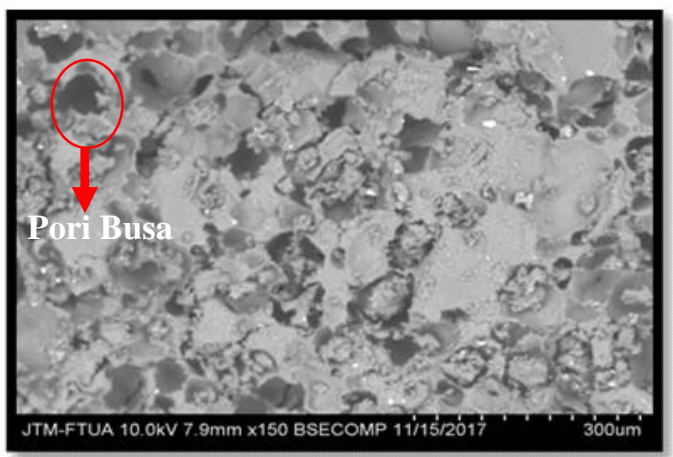

Gambar 3. Penambahan bubuk gambir $18 \mathrm{~g}$ : bubuk metode pan drying (A2B1)

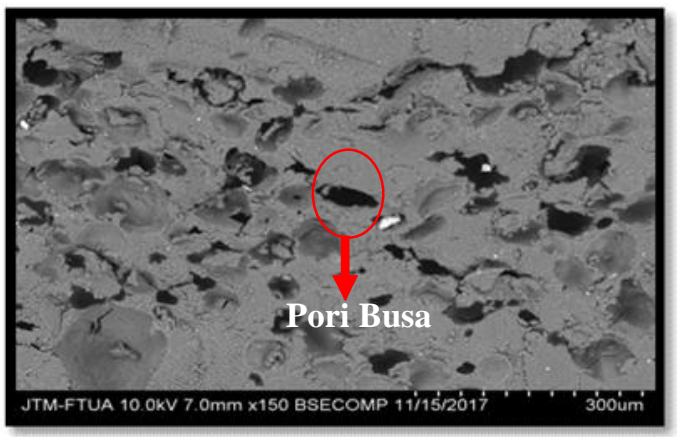

Gambar 5. Penambahan bubuk gambir $20 \mathrm{~g}$ : bubuk metode pan drying (A3B1)

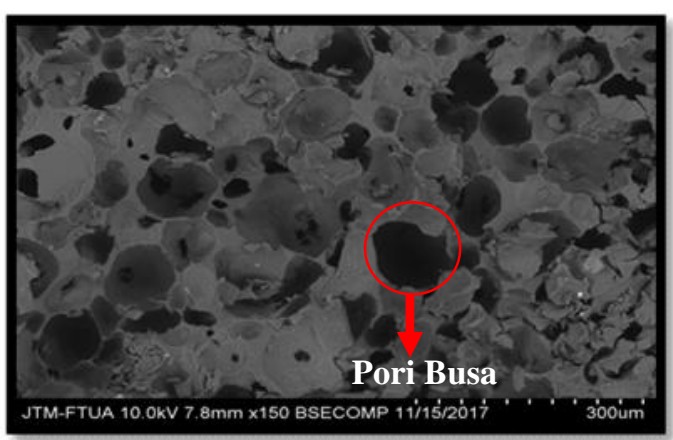

Gambar 7. Penambahan bubuk gambir $22 \mathrm{~g}$ : bubuk metode pan drying (A4B1)

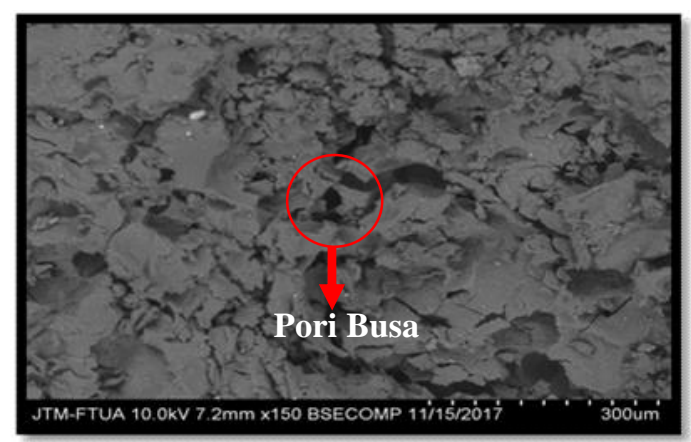

Gambar 9. Penambahan bubuk gambir $24 \mathrm{~g}$ : bubuk albumin metode pan drying (A5B1)

Dilihat dari Gambar 1-10 bahwa penampakan mikroskopik dari busa bervariasi, mulai dari diameter sel lebar (berpori) hingga rapat. Hal ini menujukkan jika penambahan konsentrasi bubuk gambir memberikan pengaruh yang nyata terhadap mikroskopik dari busa. Perlakuan yang memiliki struktur pori yang paling rapat yaitu perlakuan penambahan bubuk gambir $24 \mathrm{~g}$ dan

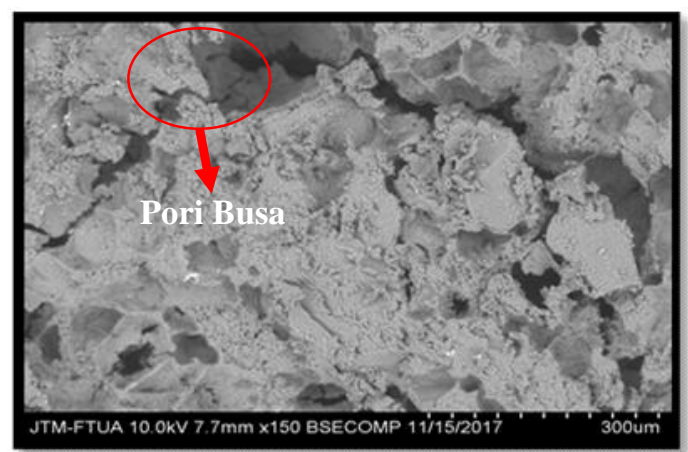

Gambar 4. Penambahan bubuk gambir $18 \mathrm{~g}$ : bubuk metode foaming drying (A2B2)

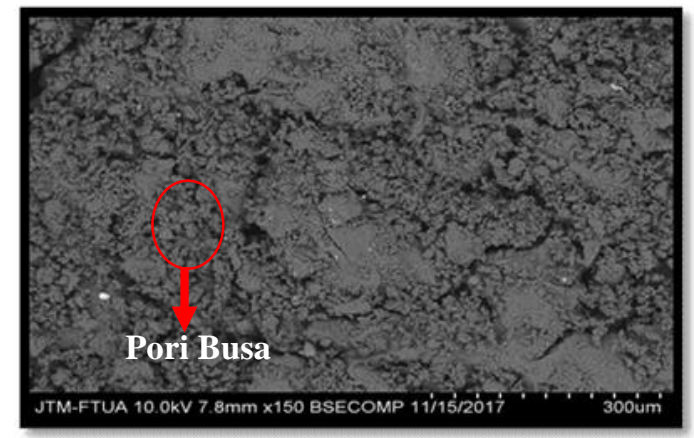

Gambar 6. Penambahan bubuk gambir $20 \mathrm{~g}$ : bubuk metode foaming drying (A3B2)

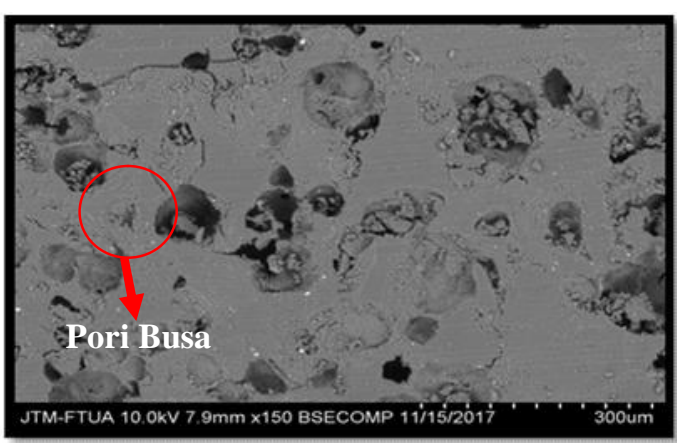

Gambar 8. Penambahan bubuk gambir $22 \mathrm{~g}$ : bubuk metode foaming drying (A4B2)

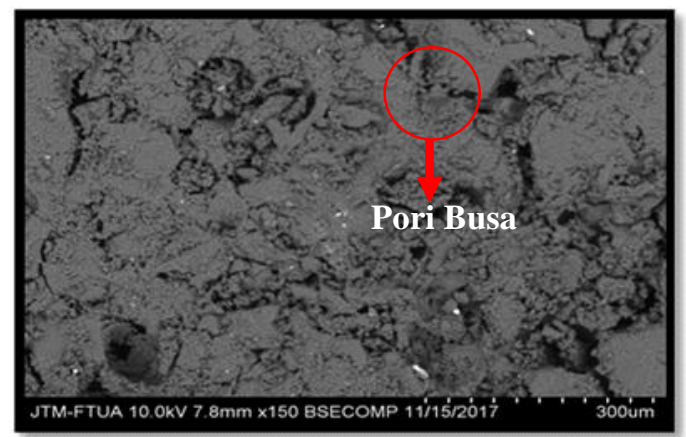

Gambar 10. Penambahan bubuk gambir $24 \mathrm{~g}$ : bubuk albumin metode foaming drying (A5B2)

bubuk albumin dengan cara pan drying serta penambahan bubuk gambir $20 \mathrm{~g}$ dan bubuk albumin dengan cara foaming drying, struktur pori yang dihasilkan dari busa berbasis tanin dan albumin berbentuk acak dan memiliki ukuran kecil-besar, pecahpecah. (Lacoste et al., 2015) menghasilkan busa berwarna coklat dengan penambahan katalis asam dan 
struktur mikroskopik busa yang dihasilkan ada juga yang memiliki struktur sel tertutup.

\section{Kesimpulan}

Peningkatan penggunaan konsentrasi bubuk gambir dengan cara penyiapan bubuk albumin menunjukkan adanya interaksi yang berpengaruh nyata pada beberapa nilai yaitu pada nilai kerapatan busa, kekuatan tekan, derajat pengembangan, $\mathrm{pH}$ dan porositas. Semakin tinggi penambahan bubuk gambir maka busa yang dihasilkan memiliki tekstur yang padat dan keras. Hasil SEM dengan perbesaran 150x untuk busa kaku menunjukkan bahwa struktur mikroskopik dari busa ada yang berpori hingga porinya sangat kecil. Secara keseluruhan fisik dari busa selama penyimpanan dan setelah penyimpanan dengan penambahan bubuk gambir yaitu busa masih tetap kokoh dan kuat.

\section{Daftar pustaka}

Anova, I.T., Kasim, A., Anggraini, T., 2018. Pengaruh komposisi ekstrak gambir pada pembuatan dan sifat fisik busa alami berbasis gambir. J. Litbang Ind. 8, 11-16. https://doi.org/10.24960/jli.v8i1.3844.23-30

Firdaus, F.E., 2014. Synthetic and characterization of soy-based polyurethane foam with utilization of ethylen glycol in polyol. Makara J. Technol 18, 1116.

Gunawan, B., Azhari, C.D., 2010. Karakterisasi spektrofotometri IR dan scanning electron microscopy (SEM) sensor gas dari bahan polimer poly ethelyn (P E G). J. Sains 1-17.

Haji, A.G., Mas'ud, Z.A., Lay, B., Sutjahjo, S., Pari, G., 2012. Karakterisasi asap cair hasil pirolisis sampah organik padat. J. Inst. Pertan. Bogor.

Kasim, A., 2011. Proses produksi dan hilir gambir. Andalas Univ. Press 101.

Lacoste, Basso, M.C., Pizzi, A., Celzard, A., Laborie, M.P., 2015. Natural albumin/tannin cellular foams. Ind. Crops Prod. 73, 41-48. https://doi.org/10.1016/j. indcrop.2015.03.087
Lagel, M.C., Pizzi, A., Giovando, S., Celzard, A., 2014. Development and characterisation of phenolic foams with phenol-formaldehyde-chestnut tannins resin. J. Renew. Mater. 2, 220-229. https://doi.org/10.7569/ JRM.2014.634113

Link, M., Kolbitsch, C., Tondi, G., Ebner, M., Wieland, S., Petutschnigg, A., 2011. Formaldehyde-free tannin-based foams and their use as lightweight panels. BioResources 6, 4218-4228. https://doi.org/ 10.15376/biores.6.4.4218-4228

Malrianti, Y., Kasim, A., Novelina, 2011. Tannins and catechins content of gambier (Uncaria gambier Roxb) in relation with adhesive qualities and bonding strengh of cold setting glue. Int. J. Adv. Res. 6, 622627. https://doi.org/10.21474/IJAR01/8181

Rahmawati, Istiqomah, T., Wardana, Lingga, W.I., 2012. Pembuatan polyurethane foam dengan menggunakan castrol oil (mimyak jarak kepyar) 1-9.

Roffael, E., Dix, B., Okum, J., 2000. Use of spruce tannin as a binder in particleboards and medium density fiberboards (MDF), in: Originalarbeiten Original. pp. 301-302.

Rohaeti, E., Suyanta, 2011. Sintesis busa poliuretan dari minyak jarak sebagai bahan isolator panas. J. Penelit. Saintek 16, 57-72.

Romanoff, A., Romanoff, A.L., 1949. The Avian Egg. Bird-Banding. https://doi.org/10.2307/4510092

Sirait, C.H., 1986. Telur dan pengolahannya. Pus. Penelit. dan Pengemb. Peternak. Bogor. 161

Szczurek, A., Fierro, V., Pizzi, A., Stauber, M., Celzard, A., 2014. A new method for preparing tannin-based foams. J. Ind. Crop. Prod. 54, 40-53.

Tondi, G., Pizzi, A., 2009. Tannin-based rigid foams : Characterization and modification. Ind. Crop. Prod. 2, 356-363. https://doi.org/10.1016/j.indcrop. 2008. 07.003

Tondi, G., Pizzi, A., Celzard, A., 2010. Tannin based foams and its derived carbon foams. PTF BPI 178180.

Toshima, O., 1994. Microcelluler polyurethane foaming by modified reaction injection molding. 